St udia Philosophica

Wratis lavien s i a

vol. XV, fasc. $1(2020)$

https://doi.org/10.19195/1895-8001.15.1.5

ROMAN KONIK

ORCID: 0000-0002-3715-3540

Uniwersytet Wrocławski

\title{
Leonardo północy. O estetyce Albrechta Dürera
}

\section{Leonardo of the North. The Aesthetics of Albrecht Dürer}

\begin{abstract}
Albrecht Dürer was German, but it was Italy he loved and followed the example of. Along with Erasmus of Rotterdam, he was one of the first to instil the ideas of Italian humanism in northern Europe, paying attention to the study of ancient culture, and thus fighting for the renewal of art in the spirit of the Renaissance. Dürer believed that using the patterns developed in Florence, the art of imaging would achieve unprecedented narrative power. The uniqueness of the artist from Nuremberg was also that he was able not only to assimilate and synthesise German Gothic art with the achievements of the Florentine school, but also to develop his own vision of the theory of art taking into account the specifics of native art. His research on the theory of movement, the implementation of objects into the structure of the image, the search for the perfect beauty in woodcut and copper engraving can be considered to be unique and pioneering projects in Germany. The influence of Dürer on the sphere of Renaissance iconography is invaluable, but unfortunately it is often omitted in the literature as secondary or even insignificant. The article shows that Dürer's theoretical influence on the shape of early modern art is noteworthy.
\end{abstract}

Keywords: Albrecht Dürer, iconic turn, aesthetics, theory of vision

O znaczeniu i interpretacji obrazu wizualnego z punktu widzenia filozofii napisano wiele prac. Poszczególne subdyscypliny wypracowały określone metody badawcze skupiające się na oddziaływaniu obrazów w sferach podmiotowej, społecznej, kulturowej czy ideologicznej. W kontekście tych badań uwzględniono 
zarówno aspekt teoriopoznawczy, psychologii percepcji, warunków kulturowych recepcji obrazu, jego oddziaływanie estetyczne, moc znakotwórczą i symboliczną przedstawień, jaki i — w ostatniej dekadzie — rolę obrazów w kulturze tak zwanych symulacrów, uwzględniając tak zwaną agonię realności obrazów. W mnogości publikacji na szczególną uwagę zasługują te rozważania, które koncentrują się na kluczowych momentach w historii obrazowania. Tak zwany zwrot ikoniczny w naukach o kulturze wizualnej związany jest pośrednio z wieloma koncepcjami (niekoniecznie z zakresu nauk humanistycznych), jak choćby z teorią paradygmatów badawczych w filozofii nauki Th. Khuna, czy też badaniami z zakresu epistemologii P. Feyerabenda, a także z pracami filozofów określanych mianem postmodernistów. Tego rodzaju analizy wskazują na kluczowe momenty w historii rozwoju nauki i szeroko rozumianej kultury, koncentrując się na przełomowych momentach, które możemy określić mianem zerwania i dyskontynuacji. Na gruncie Visual Culture Studies G. Boehm ${ }^{1}$ oraz H. Brodekamp ${ }^{2}$, sięgając do historii tworzenia przedstawień, wskazują na ważne momenty w kulturze wizualnej, w których pojawiały się nowe formy obrazów, które zrywają wypracowane i ugruntowane tradycją koncepcje, proponując w zamian nowe rozwiązania, nie tylko w zakresie technik wytwarzania przedstawień, lecz także zmiany w procesach odwzorowywania, reprezentowania, oddziaływania, a tym samym nowych funkcji obrazu. Omawiane zmiany nie mają charakteru kumulatywnego, a także nie noszą wyłącznie znamion tak zwanego przestylizowania, mają raczej charakter zmian całościowych, redefinujących obraz (zmiany dotyczą sposobu formowania obrazu, zmienne są też narzędzia i samo tworzywo obrazu, tym samym zmienia się zarówno jego jakość, jak i funkcja oddziaływania tak zwanego pola obrazowego). W tak zarysowanej perspektywie badawczej na gruncie Visual Culture Studies stawiane są fundamentalne pytania dotyczace istoty widzenia, mediacji obrazowej między naszą świadomością a światem zewnętrznym, budowania sensu obrazu, roli doświadczenia wzrokowego, relacji podmiotu do obrazu i przypisywania mu określonych wartości. Większość współczesnych analiz z tego zakresu koncentruje się na porzuceniu tak zwanego obrazu sztalugowego i skupia się na problematyce związanej z obrazem niematerialnym (cyfrowym), analizując jego niematerialność, charakter wirtualny bądź immersyjny. Tego rodzaju analizy, jakkolwiek cenne, mają w dużej mierze charakter badań interwencyjnych, gdyż przedmiotem badań jest obraz cyfrowy będący ciągle w fazie in status nascendi. Badanie obrazotwórczej mocy przedstawień nie może rezygnować z perspektywy historycznej, obrazy w naszej cywilizacji mają swoją historię, w której kryją się wzajemne zależności, oddziaływania i przyczyny. Wszelkie publikacje podejmujące historyczne uwarunkowania rozwoju obrazów, analizując ich zależność od filozofii czy rozwoju nauk przyrodniczych, nie tylko wzbogacają historię kultury wizualnej, ale pozwalają lepiej zrozumieć rolę obrazu we współczesnej kulturze i jego związki z dominującym paradygmatem naukowym.

${ }^{1}$ Por. G. Boehm, O obrazach i widzeniu. Antologia tekstów, D. Kołacka (red.), tłum. M. Łukasiewicz, A. Pieczyńska-Sulik, Kraków 2014.

${ }^{2}$ H. Bredekamp, Drehmomente, Merkmale und Ansprüche des „iconic turn”, [w:] Iconic Turn. Die neue Macht der Bilder, Ch. Maar, H. Burda (red.), Köln 2004, s. 16-17. 
Panuje powszechne przekonanie, że źródeł nowożytnego obrazu należy poszukiwać na początku XV wieku we Florencji. Takie postacie jak L.B. Alberti, L. da Vinci, Masaccio, F. Brunelleschi czy C. Cennini wyznaczają horyzonty zmian w formowaniu się nowożytnych sztuk plastycznych. Wskazanie na neoplatończyków florenckich jako protagonistów obrazu iluzyjnego jest ze wszech miar właściwe, lecz w tego rodzaju zestawieniach nie należy pomijać Albrechta Dürera. Często zapomina się o tym, że za twórczą recepcją idei renesansowych na północy Europy stał jeden człowiek: mistrz z Norymbergii, który działał w pełnej izolacji, niejednokrotnie osamotniony i bez zrozumienia. Artysta był w sytuacji wyjątkowo trudnej, nie tylko ze względu na izolację artystyczną. Należy pamiętać, że Włosi od czasów Dantego posługiwali się wyrafinowanym i finezyjnym językiem, w którym formułowano teorię sztuki (większość traktatów renesansowych pisana była już po włosku). Dürer musiał konstruować zręby nowej estetyki w języku mistrza Eckharta (który zawiłe kwestie mistyczne i tak opisywał po łacinie) i Lutra. Może też z tego powodu Albrecht Dürer tak długo borykał się z omówieniem głównych zagadnień filozofii sztuki w eseju, do którego wielokrotnie powracał, i mimo składanych deklaracji i zapewnień, że dzieło jest gotowe (w 1512 roku), nigdy go nie ukończył. Jego nowatorskie idee dotyczace estetyki obrazu nie odnajdywały w Niemczech zanurzonych w estetyce gotyku akceptacji. Dopiero z czasem propozycje estetyki dürerowskiej, w której łączono akt twórczy z baczną obserwacją natury, ale także z zasadami geometrii rzutowej, optyki i badaniami z zakresu filozofii przyrody, przyczyniły się nie tylko do zmian na gruncie sztuki północy, lecz także do redefincji samego artysty: Albrecht Dürer, jako jeden z pierwszych artystów północy, widzi siebie bardziej jako filozofa, badacza i matematyka niż artystę. Tym samym wychodzi z ciasnego kręgu zajęć rzemieślniczych, w których plastyka jest zaliczana do działań pospolitych (artes vulgares) ${ }^{3}$. Jak już wspomniałem, wkład niemieckiego teoretyka i artysty z Norymbergii często bywa pomijany bądź sytuowany w kontekście badań wtórnych wobec włoskich artystów, których niejednokrotnie określano mianem „terrorystów estetycznych" ze względu na ich dominujący wkład w sztuki plastyczne w renesansie. Wpływ Dürera na sferę ikonografii renesansowej jest nieoceniony, niestety często w literaturze przedmiotu pomijany jako drugorzędny i nieistotny. Mistrz z Norymbergii często sytuowany jest w cieniu renesansowej sztuki włoskiej jako postać wtórna i drugorzędna. Jednak rola Albrechta Dürera jest niepodważalna, był on największym teoretykiem sztuki i artysta przełomu XVI i XVII wieku w Niemczech.

Jak słusznie zauważa Władysław Tatarkiewicz: „Dürer był Niemcem, ale Włochy były jego miłością i wzorem"4. Oprócz Erazma z Rotterdamu był jednym z pierwszych, którzy zaszczepili idee włoskiego humanizmu na teranie północnej Europy, przywiązując wagę do studiów nad kulturą antyczną, a tym samym walcząc o odnowę sztuki w duchu renesansu. Dürer uważał, że za pomocą wypracowanych we Florencji wzorców sztuka obrazowania osiągnie niespotykaną dotychczas moc narracyjną. Niezwykłość artysty z Norymbergii polegała też na tym, że potra-

${ }^{3}$ Por. T. Białostocki, Teksty źródłowe do dziejów teorii sztuki, t. 5. Albrecht Dürer jako pisarz i teoretyk sztuki, Wrocław 1956, s. XX.

${ }^{4}$ Por. W. Tatarkiewicz, Historia estetyki, t. 3. Estetyka nowożytna, Warszawa 1991, s. 231. 
fił nie tylko zasymilować i zsyntetyzować sztukę gotycką Niemiec z osiągnięciami szkoły florenckiej, lecz także wypracować własną wizję teorii sztuki uwzględniającą specyfikę sztuki rodzimej. Jego badania nad teorią ruchu, implementacji przedmiotów w strukturę obrazu (Dürer wzorem L. da Vinci projektował tak zwane maszyny rzutujące), poszukiwania idealnego piękna w drzeworycie i miedziorycie można uznać za przedsięwzięcia endemiczne na terenie Niemiec. Być może trafne jest określenie, że artyzm Dürera polegał na gotyckich wariacjach na temat obrazu renesansowego. Sam mistrz z Norymbergii miał świadomość przecierania szlaków w sztuce niemieckiej, próbował budować coś „,czego prędzej nie widziano”. Sięgnięcie w analizach po Albrechta Dürera i ponowna próba odczytania jego wielkiego i nowatorskiego (na gruncie XVI wiecznej sztuki północnych Niemiec) projektu sztuk plastycznych może wzbogacić badania, nie tylko w kontekście historii sztuki, ale przede wszystkim w zakresie historycznej zmienności formowania i recepcji obrazu. Warto chociażby zwrócić uwagę na próbę połączenia prac graficznych mistrza z Norymbergii z osobistym elementarzem aksjomatów etycznych, a także z silnym powiązaniem grafiki z symbolem. Ukazanie relacji łączących notacje graficzne z aksjomatami etycznymi jest wielowarstwowe i skomplikowane, wymaga wiedzy nie tylko z zakresu historii sztuki, filozofii, teologii, lecz także semiologii, filozofii przyrody, optyki i estetyki. W tego rodzaju badaniach należy w pierwszej kolejności uwzględnić specyficzny czas, w których powstawały prace Dürera. Jest to historyczny moment, w którym wzrokowe doświadczenie obrazu przechodzi swoistą volte, nowatorskie zastosowanie technik malarskich (przez wykorzystanie perspektywy zbieżnej i światłocienia w kontekście chromatyki obrazów, a tym samym nadanie niespotykanego wymiaru iluzyjnego malarstwu) zmienia nie tylko w sposób istotny kompozycję obrazu, ale łączy pracę artysty z badaniami z zakresu nauk matematycznych i przyrodniczych, a tym samym zmienia akt postrzegania natury i jej implementacji w obraz. Formowanie obrazu o nowe przesłanki zmienia również relację między przedmiotem i jego przedstawieniem, zmienia w końcu tėz namysł nad rolą i funkcją eikones dla kultury wizualnej, a także stawia wiele pytań dotyczących poznawczej funkcji obrazu.

Prace Albrechta Dürera (zarówno jego miedzioryty, drzeworyty, jak też prace graficzne, jak choćby cykl Wielka i Mała Pasja, Apokalipsa czy Marienlieben) moga być podstawą do wydobycia z warstwy graficznej licznych wątków aksjologicznych bliskich artyście. W zasadzie każdej z grafik Dürer można przypisać konkretne pojęcie etyczne. Tak przyjęta zasada pozwala nie tylko na uporządkowanie katalogu pojęć, które stanowią etyczny elementarz Dürera, lecz także na zwrócenie uwagi na osobne omówienie kwestii kompozycyjno-warsztatowych poszczególnych grafik. Tak przyjęta metodologia wskazuje na istotny kontekst sfery ikonograficzno-semiologicznej, który uwzględniałby wszelkie konteksty historyczne, zagadnienia techniczne, mające na celu zrozumienie epoki, itp. Warto także pamiętać o tym, że sam Dürer niektóre sceny biblijne przedstawiał kilka razy, jak choćby w cyklu grafik Marienlieben, w której ukazał pokłon trzech króli. Artysta ponownie, lecz w odmienny sposób namalował w 1504 roku tę samą scenę w obrazie Pokłon Trzech

${ }^{5}$ E. Panofsky, The Life and Art of Albrecht Dürer, Princeton 1967, s. 122. 
Króli (obraz ten powstał na zlecenie Fryderyka III Mądrego do kaplicy zamkowej w Wittenberdze w Saksonii). Pomijając już ewidentny wpływ Andrei Mantegni na mistrza z Norymbergii, warto pamiętać, że w postaci trzech mędrców (przypominają tych z grafik) możemy dostrzec podobizny zleceniodawcy Martina Paumgartnera i jego synów: Łukasza i Stefana, zaś w rysach twarzy Matki Chrystusa można się dopatrzyć podobieństwa do żony artysty Agnes Frey. Tego rodzaju informacje nie tylko wzbogacają wiedzę o poszczególnych pracach, ale ukazują rozwój artysty, który dodawał ważne wątki kompozycyjne i interpretacyjne.

Albrecht Dürer był na terenie Niemiec pierwszym artystą, który dzięki neoplatonikom z Florencji zrozumiał wagę studiów z zakresu filozofii przyrody. Warto tu odnotować, że podczas wyjazdów do Włoch Dürer niewątpliwie kontaktował się z przedstawicielami szkoły florenckiej. Wedle Erwina Panofskiego nie ma wątpliwości, że artysta spotkał się z matematykiem Luca Paciolim i wielkim architektem Donato Bramantem, a być może również z samym Rafaelem Santim6 ${ }^{6}$ Dzięki włoskim neoplatonikom na grunt grafiki niemieckiej Dürer wniósł zagadnienie perspektywy i mistrzowskiego operowania światłem. Tego rodzaju badania implikował na grunt sztuki w postaci krajobrazów, wizerunków zwierząt i finezyjnych motywów ze świata roślin. Z tego też powodu grafiki Dürera należy w pierwszej kolejności odczytywać jako prace skomponowane w estetyce ekspresyjno-naturalistycznej, różni je od grafik średniowiecznych to, że nie każdy element implikowany w strukturę grafiki musi mieć znaczenie symboliczne i odsyłać do określonych znaczeń, może on odgrywać wyłącznie rolę stosownego decorum. Zdarza się jednak, że w interpretacjach grafik Albrechta Dürera zapomina się o tym istotnym szczególe, próbując odczytywać jego kompozycję przez gotycką estetykę. Uwzględnienie wpływu florenckich mistrzów jest fundamentalne i chroni przed mylnym bądź czysto fiducjarnym łączeniem warstw graficznej z wydobyciem określonych stanowisk etycznych mistrza z Norymbergii. W kontekście tego rodzaju uwag należy pamiętać, że analiza treści zawartych w komunikatach graficznych ma dość bogatą tradycję filozoficzną reprezentowaną głównie w badaniach semiologicznych. Znak, a w szczególności znak graficzny musi być zawsze osadzony w konkretnej epoce, każda zaś epoka posługiwała się konkretnym kodem graficznym, na który wpływały liczne determinanty i kategorie formalne (zaczerpnięte często z obowiązującej filozofii) i pozostajace z sobą w określonych relacjach. By ten kod poprawnie odczytać należy zastosować określony zestaw reguł interpretacyjnych, który umożliwi nie tylko prawidłowe odczytanie intencji artysty, lecz także wskaże historyczne uwarunkowania między nadawcą i odbiorcą znaku. Warto przy analizach grafik Dürera sięgnać po prace semiologiczne Umberta Eco dotyczacce estetyki średniowiecza ${ }^{7}$. Autor w Sztuce $i$ pięknie średniowiecza przedstawia w zarysie historię teorii estetycznych dominujacych od VI do XV wieku, wiążąc je mocno ze stanowiskami filozoficznymi i teologicznymi wypracowanymi na gruncie tradycji łacińskiej. Należy pamiętać, że sztuka dürerowska, mimo fascynacji włoskim renesansem, była mocno osadzona w kulturze wizualnej późnego średniowiecza. W kontekście

${ }^{6}$ Por. E. Panofsky, The Life and Art of Albrecht Dürer, Princeton 1967, s. 252.

${ }^{7}$ U. Eco, Sztuka i piękno w średniowieczu, tłum. M. Olszewski, M. Zabłocka, Kraków 1997. 
tego rodzaju badań warto też skorzystać z prac poświęconych znakom ikonicznym i próbom ich deszyfryzacji w kontekście estetyki, teologii czy szeroko ujmowanej aksjologii ${ }^{8}$.

Aby ukazać wielowarstwowość interpretacji znaków graficznych w kontekście zagadnień etycznych autora Melancholii, można posłużyć się grafiką Sanctitas, obrazującą Narodzenie Maryi. Strategię deszyfryzacji znaków można oprzeć na ewidentnym nawiązaniu do przedstawionej w grafice liczby postaci (12), całkowicie pomijając oczywisty fakt, że zobrazowana akcja rozgrywa się w obrębie dwu kompozycyjnych trójkątów (kształtu zasłony łoża i ukształtowania grupy kobiet z dzieckiem). Trójkąt i liczba trzy są istotnymi i często powtarzanymi motywami w grafikach Dürera i stanowią ewidentną aluzję do Trójcy Świętej. Analizując grafiki z cyklu Marienleben, należy pamiętać, że dürerowska kompozycja oparta była na założeniach teoretycznych Szkoły Florenckiej, skodyfikowanej w Traktacie o malarstwie Leona Battisty Albertiego ${ }^{9}$ (co szczegółowo omawia F. Kittler ${ }^{10}$, w sposób niezwykle drobiazgowy ukazując związki Dürera ze sztuką wczesnego renesansu). Z tego też powodu przestrzeń grafik Dürera należy interpretować w duchu wczesnego renesansu jako przestrzeń agregatową, specjalnie umieszczaną w kompozycji okna lub łuków architektonicznych, w celu zwiększenia efektu perspektywicznego. Te zabiegi mają charakter stricte kompozycyjny i niekoniecznie mają związek z wymiarem symbolicznym. Przedstawiane detale, jak ramy, wnętrze pokoju, czy zamknięta kompozycja w formie tak zwanej klatki rzutowej odgrywają po prostu rolę zwykłego decorum (podobnie jak romboidalna szachownica posadzki w twórczości florentczyków pełniąca funkcję znaku firmowego szkoły, substytut podpisu). Jak wielką wagę do tego rodzaju rozwiązań teoretyczno-kompozycyjnych przywiązywał Dürer wystarczy przeczytać jego Pouczenie o mierzeniu cyrklem i linia ${ }^{11}$, jest to ewidentnie teoretyczna kontynuacja prac L.B. Albertiego. Wystarczyłoby też prześledzić rysunki techniczne mistrza z Norymbergi, by dostrzec nadrzędność kompozycyjną algorytmów linearno-perspektywicznych w stosunku do przedstawianych treści. Pisze o tym wyczerpująco J. Sprutta w artykule Sztuka religijna Albrechta Dürera ${ }^{12}$. Estetyka grafik Dürera jest co prawda jeszcze mocno zakorzeniona w gotyckich poszukiwaniach uniwersaliów. Jednak nowatorstwo jego grafik polega na tym, że artysta ma świadomość tego, że dobra grafika cechująca się umiejętnością praktyczno-warsztatową jest nie tylko efektem żmudnych ćwiczeń, lecz także efektem solidnego wglądu teoretycznego w to, co zwiemy nauką.

\footnotetext{
${ }^{8}$ Por. zwłaszcza U. Janicka-Krzywda, Patron-atrybut-symbol, Poznań 1993; W. Hütt, Niemieckie malarstwo i grafika późnego gotyku i renesansu, tłum. S. Błaut, Warszawa 1985, która jest obszerną monografia poświęconą związkom ikonografii maryjnej z literaturą apokryficzną; M. Feuillet, Leksykon symboli chrześcijańskich, tłum. M. Paleń, Poznań 2006; K. Klauze, Teokalia. Piękno Boga. Prolegomena do estetyki dogmatycznej, Lublin 2008; C. Bartnik, Matka Boża, Lublin 2003; J. Marecki, L. Rotter, Jak czytać wizerunki świętych. [Leksykon atrybutów i symboli hagiograficznych], Kraków 2009; M. Paltrinieri, F. de Poli, Geniusze sztuki. Dürer, tłum. B. Toeplitz-Kaczmarek, Warszawa 1991; G. Drescher, Dürers Marienleben, Schweinfurt 2005.

${ }^{9}$ L.B. Alberti, O malarstwie, tłum. L. Winniczuk, Wrocław 1963.

${ }^{10}$ F. Kittler, Ksiazkka i perspektywa, tłum. B. Balicki, Warszawa 2014.

11 T. Białostocki, op. cit., s. 111-112.

12 J. Sprutta, Sztuka religijna Albrechta Dürera, „Studia Gnesnensia” 27 (2013), s. 339-357.
} 
Co prawda, gotycka sztuka dawała również wskazówki dotyczące zasad rysunku (traktując rysunek jako techné, a więc umiejętność czysto warsztatową), ale nie dostarcza żadnego naukowego wyjaśnienia budowy poszczególnych elementów, ich wzajemnego oddziaływania czy reagowania na naturę światła. Rola renesansowego artysty nie ograniczała się już do konstruowania przedstawienia rzeczy wedle subiektywnego klucza imitacyjnego (często dalece umownego w stosunku do naturalnego oglądu), lecz do przedstawiania rzeczy tak, jak są widziane w naturalnym akcie postrzegania. Renesansowy artysta musiał więc znać nie tylko zasady jawienia się przedmiotów, lecz także zasady ich budowy i działania, by mógł go na nowo „odtworzyćc w przestrzeni obrazu. Innymi słowy, zwrot, który widzimy w teorii Dürera, polegał na uświadomieniu sobie tego, że dotychczasowe gotyckie reguły są co prawda potrzebnym kodeksem zasad twórczości plastycznej, ale nie dają niestety koniecznej teorii (nauki) potrzebnej do prawomocnego (poprawnego) implementowania natury i wyobrażeń w przestrzeń obrazu.

Dürer, wzorem włoskich neoplatoników, niezależnie od doskonalenia zdolności warsztatowych zajmował się zbieraniem informacji o zjawiskach przyrodniczych, o strukturze i budowie ciała ludzkiego, o jego motoryce, o sposobach wyrażania emocji w gestach i fizjonomii, studiował budowę roślin, badał naturę światła itd. Wszystkie te zabiegi uzupełniały proces twórczy konieczną teorią, dzięki której artysta mógł w dwuwymiarowej przestrzeni obrazu ukazać obiekty w złudzeniu trzech wymiarów. Tego rodzaju działania łączące sztukę z badaniami z zakresu nauk przyrodniczych, optyki, geometrii, mechaniki, geologii czy meteorologii stają się wyznacznikiem nowej sztuki, których pełnoprawnym uczestnikiem i twórcą jest Dürer. Wkład Dürera w teorię sztuki widać też w batalii, którą stoczył w Norymberdze, o uznanie malarstwa jako jednej ze sztuk wyzwolonych, oddzielając tym samym cech rysowników od grupy rzemieślników. Jest to jedna z głównych teorii okresu renesansu i nie ma wątpliwości, że płomiennym rzecznikiem wyłączenia sztuk plastycznych z rzemiosła był na terenie Niemiec Dürer.

Kolejną kwestią, na którą warto zwrócić uwagę, jest widoczny przełom kompozycyjny w grafikach dürerowskich sprzed przełomowej podróży do Włoch (w 1495 roku do Wenecji, w latach 1505-1507 do Wenecji, Florencji i Bolonii) i powrocie do Norymbergii. Grafiki i rysunki przed podróżą do Włoch pokazują, jak dalece artysta był zanurzony w warsztacie gotyckim. Porównując wczesne prace artysty z jego późniejszymi grafikami, obrazami i drzeworytami łatwo wykazać, jak dalece przekonania teoretyczne renesansu wpłynęły na stronę kompozycyjną oraz na kwestie warsztatowe. Przy tej okazji można też ukazać niepospolitość Dürera, jego odwage przejawiającą się w umiarkowanym krytycyzmie, w stosunku do filozofii sztuki włoskiego renesansu. Właśnie w cyklu grafik Marienleben Dürer pokazał, że stosując nowatorską kompozycję obrazu zakorzeniony i przywiązany jest do tematyki późnego średniowiecza (podejmuje zagadnienia eschatologii poprzez ukazanie historii zbawienia w ilustracjach z historii życia rodziców Matki Bożej i jej samej, korzystając przy tym nie tylko z kart ewangelii, lecz także z protoewangelii i apokryfów), tym samym daleki jest od laicyzowania sztuki wzorem Włochów.

W biografii twórczej mistrza z Norymbergii nie brakuje również zagadkowych kwestii. Dürer nie krył swych sympatii do poglądów Lutra, ten zaś był wyjątkowo 
sceptycznie nastawiony do kultu maryjnego. Dürer z jednej strony sympatyzuje z duchem reformy Lutra i jego niechęcią do kultu maryjnego, z drugiej zaś poświęca cykl grafik Matce Chrystusa, nie kryjąc tym samym ogromnej czci dla Niepokalanej.

Podsumowując, warto zwrócić szczególną uwagę na wpływ Dürera na kształtowanie się tego, co możemy nazwać kulturą wizualną Europy w wieku XV i XVI. Należy pamiętać, że to dzięki jego teoretycznym pracom i zastosowaniu ich w praktyce grafika niemiecka w XVI wieku odegrała ogromną rolę w ówczesnej Europie. Na szczególną uwagę zasługuje technika drzeworytu, tak doskonale opanowana przez artystę, który nadał jej niespotykaną finezję wraz ze światłocieniowym modelunkiem, miękkością przejść tonalnych zbliżoną do malarstwa. Drzeworyt z kolei został spopularyzowany w Niemczech wraz z rozwojem drukarstwa, zaczynajacc początkowo od służebnej roli ilustracyjnej (głównie ilustracji do Biblii), by z czasem zyskać rangę samodzielnej techniki plastycznej. Należy pamiętać, że grafiki Dürera powstawały w Norymberdze, miasto to było zaś rodzinnym miastem Gutenberga. Jeszcze za życia artysty Norymberga stała się potężnym ośrodkiem wydawniczym i miejscem handlu książkami, to z kolei wpłynęło na ukształtowanie się wrażliwości wizualnej epoki renesansu w Niemczech i krajach ościennych. Nie bez znaczenia dla kształtowania się wrażliwości ikonograficznej wczesnego renesansu były właśnie norymberskie wydruki grafik Dürera. Zachwycały nowatorską kompozycją obrazu, doskonałością odzwierciedlenia świata natury, stanowiły często inspirację dla innych artystów, nie tylko na gruncie malarstwa czy grafiki, lecz także zdobnictwa, rzeźby, a nawet kaligrafii. Należy też pamiętać o dürerowskim zastosowaniu geometrii do konkretnych zadań architektury, inżynierii, dekoracji, a także typografii gotyckiej. Nowatorstwo w typografii gotyckiej polegało na tym, że Dürer w odróżnieniu od obowiązujących powszechnie zasad które nakazywały wpisanie każdej gotyckiej litery (wraz z okrągłymi łukami) w kwadrat, ustalił własne proporcje. Propozycja liternictwa dürerowskiego rezygnuje z liter z łukami, są one zastąpione prostymi liniami w ramach zwielokrotnionych kwadratów i trapezoidów. Nawet w tak drugorzędnych kwestiach jak typografia widać u Dürera pragnienie dążenia do estetycznej dokładności i poprawności opartej na badaniach geometrycznych. W propozycji nowej kaligrafii widać także entuzjazm Dürera dla antycznych rozwiązań w zakresie decorum. Gotyckie litery, wedle artysty, mają być symbolem nowej estetyki i mają odzwierciedlać powrót do rozwiązań klasycznych (nawiązując do porządku jońskiego, korynckiego czy doryckiego w architekturze).

\section{Bibliografia}

Alberti L.B., O malarstwie, tłum. L. Winniczuk, Wrocław 1963.

Bartnik C., Matka Boża, Lublin 2003.

Białostocki T., Albrecht Dürer jako pisarz i teoretyk sztuki, Wrocław 1956.

Boehm G., O obrazach i widzeniu. Antologia tekstów, D. Kołacka, tłum. M. Łukasiewicz, A. Pieczyńska-Sulik (red.), Kraków 2014.

Drescher G., Dürers Marienleben, Schweinfurt 2005. 
Eco U., Sztuka i piękno w średniowieczu, tłum. M. Olszewski, M. Zabłocka, Kraków 1997. Feuillet M., Leksykon symboli chrześcijańskich, tłum. M. Paleń, Poznań 2006.

Hütt W., Niemieckie malarstwo i grafika późnego gotyku i renesansu, tłum. S. Błaut, Warszawa 1985.

Janicka-Krzywda U., Patron-atrybut-symbol, Poznań 1993.

Kittler F., Ksiazka i perspektywa, tłum. B. Balicki, Warszawa 2014.

Klauze K., Teokalia. Piękno Boga. Prolegomena do estetyki dogmatycznej, Lublin 2008.

Marecki J., Rotter L., Jak czytać wizerunki świętych. [Leksykon atrybutów i symboli hagiograficznych], Kraków 2009.

Paltrinieri M., Poli F. de, Geniusze sztuki. Dürer, tłum. B. Toeplitz-Kaczmarek, Warszawa 1991.

Panofsky E., The Life and Art of Albrecht Dürer, Princeton 1967.

Sprutta J., Sztuka religijna Albrechta Dürera, ,Studia Gnesnensia” 27 (2013), s. 339-357.

Tatarkiewicz W., Historia estetyki, t. 3. Estetyka nowożytna, Warszawa 1991. 